\title{
PELATIHAN KONSELING KESEHATAN REMAJA UNTUK MENINGKATKAN EFIKASI DIRI KONSELOR SEBAYA PADA SISWA SEKOLAH MENENGAH ATAS
}

\section{ADOLESCENT HEALTH COUNSELINGTRAINING TO IMPROVE PEER COUNSELOR SELF-EFFICACY ON HIGH SCHOOL STUDENTS}

\author{
Muhammad Arif Rizqi \\ H. Fuad Nashori \\ Yulianti Dwi Astuti \\ Program Studi Psikologi Profesi (S2), Universitas Islam Indonesia, Yogyakarta \\ Email:marief_kompa5@yahoo.com
}

\begin{abstract}
The purpose of this study was to evaluate the effectivity of Adolescent Health Counseling Training in improving peer counselor self-efficacy on high school students. There were three participants enrolled this study.Peer counselor self-efficacy was measured by using self-efficacy scale. Data were analyzed using nonparametric Wilcoxon test to see differences in peer counselor self-efficacy before and after intervention. The result shown no significant effect of Adolescent Health Counseling Training in improving peer counselor selfefficacy $(p=0,150)$. Qualitative analyzed showed that self-efficacy of peer counselor improves peer counselor self-efficacy after intervention.
\end{abstract}

Keywords: Peer Counselor, Adolescent Health Counseling Training, Self-Efficacy

\begin{abstract}
ABSTRAK
Tujuan dari penelitian ini adalah untuk mengetahui pengaruh Pelatihan Teknik Konseling Kesehatan Remaja untuk meningkatkan efikasi diri konselor sebaya SMA Z. Subjek dalam penelitian ini adalah tiga siswa kelas XI semester 1. Efikasi diri konselor sebaya diukur menggunakan skala efikasi diri konselor sebaya. Desain penelitian yang digunakan adalah one group pretest and posttest design. Data yang diperoleh kemudian dianalisis menggunakan metode non parametric Wilocoxon test untuk melihat perbedaan skor efikasi diri konselor sebaya sebelum dan setelah diberikan intervensi. Hasil analisis data secara kuantitatif menujukkan bahwa tidak ada pengaruh Pelatihan Teknik Konseling Kesehatan Remaja untuk meningkatkan efikasi diri konselor sebaya SMA Z dengan nilai $p=0,150(p>0,05)$. Hasil analisis secara kualitatif menunjukkan bahwa efikasi diri konselor sebaya mengalami peningkatan.
\end{abstract}

Kata Kunci: Konselor Sebaya, Pelatihan Konseling Kesehatan Remaja, Efikasi Diri

Mayoritas remaja dewasa ini dihadapkan pada lingkungan yang kurang stabil dibandingkan dengan satu atau dua dasawarsa yang lalu. Perilaku-perilaku berisiko tinggi pada remaja seringkali tumpang tindih dengan empat bidang kepri- hatinan khusus, yaitu kenakalan remaja, penyalahgunaan obat-obatan, kehamilan remaja, dan masalah-masalah yang berkaitan dengan sekolah (Santrock, 2002). Berdasarkan data Kementerian Kesehatan RI, ada beberapa fakta yang menunjukkan 
bahwa remaja Indonesia saat ini menghadapi berbagai tantangan, yaitu perilaku beresiko, pengetahuan, dan akses terhadap informasi (Pedoman Standar Nasional Pelayanan Kesehatan Peduli Remaja, 2014).

Sebagai bentuk respon dan tindak lanjut dari kondisi tersebut, Kepala Sekolah SMA X merasa perlu adanya upaya yang lebih intensif yang melibatkan guru, siswa, orang tua serta psikolog dalam upaya mencegah terjadinya perilaku berresiko di kalangan siswa. Selain itu juga sebagai upaya antisipasi terjadinya peristiwa kehamilan tidak diinginkan (KTD), maka pihak sekolah bekerjasama dengan Puskesmas Ngaglik II menyelenggarakan program pembinaan remaja.

Upaya pembinaan remaja di SMA X sudah dilakukan. Salah satu dari upaya tersebut adalah dengan melakukan kegiatan Konseling Kesehatan Remaja (KKR). Konseling Kesehatan Remaja (KKR) merupakan kegiatan yang mewakili Pelayanan Kesehatan Peduli Remaja (PKPR) yang diselenggarakan untuk memenuhi kebutuhan remaja dan meningkatkan daya tahan remaja terhadap berbagai masalah yang dialaminya sehingga mereka mampu memelihara kesehatan dan terhindar dari perilaku beresiko. Salah satu bentuk konkret dari kegiatan Konseling Kesehatan Remaja adalah dengan pembentukan konselor sebaya.
Newcomb dan Bentler (Santrock, 2002) menjelaskan bahwa dukungan sosial selama masa remaja secara nyata akan mampu mengurangi perilaku berresiko. Dukungan sosial tersebut meliputi relasi yang baik dengan orang tua, saudara-saudara kandung, orang dewasa, dan teman-teman sebaya.

Sejalan dengan hal tersebut, Cohen dkk (Santrock, 2002) menemukan bahwa orang tua, teman sebaya, dan dukungan sosial memainkan peran penting dalam pencegahan perilaku beresiko pada remaja. Sementara itu, Cowie dan Wallace (Suwarjo, 2008) menemukan bahwa dukungan teman sebaya banyak membantu atau memberikan keuntungan kepada anak-anak yang memiliki persoalan sosial dan keluarga, dapat membantu memperbaiki iklim sekolah, serta memberikan keterampilan sosial.

Geldard (2014) menyatakan bahwa program pelatihan konseling sebaya sangat disarankan karena memberikan remaja suatu keterampilan untuk saling membantu satu dengan yang lain dalam membicarakan masalah dan mengatasi isu-isu yang meresahkan. Di samping itu, konselor sebaya yang terlatih dengan baik dapat mendorong remaja yang mengalami masalah serius untuk mengambil langkah menemui seorang konselor profesional. Selain itu, program pendidikan dapat digunakan untuk mengajari remaja untuk mengatasi dan mengelola stres, mem- 
bangun hubungan sosial positif, bertanggung jawab, dan belajar bagaimana mengurus kesehatan fisik dan psikologis.

Tiego dan Kamore (2015) menyebutkan hasil penelitian di beberapa negara menunjukkan bahwa pelatihan bagi konseling sebaya yang efektif menggunakan analisis kebutuhan (need assessment) pada sekolah dan mengembangkan pelatihan yang relevan bagi konselor sebaya agar program tersebut sukses.

Berdasarkan hasil analisis kebutuhan (need assessment) yang peneliti lakukan kepada konselor sebaya dan guru BK di SMA X diperoleh informasi bahwa kebutuhan dan masalah yang dihadapi oleh konselor sebaya adalah ketidakmampuan melakukan konseling dengan baik serta sikap konselor yang kurang baik. Selain itu masalah lain yang dihadapi adalah belum memiliki bekal bagaimana cara-cara melakukan konseling yang baik dan benar. Konselor sebaya yang baru merasa belum mampu melaksanakan tugasnya dengan baik karena belum memperoleh pembekalan atau pelatihan.

Pada kesempatan lain, melalui suatu wawancara dengan peneliti, beberapa konselor sebaya menyampaikan bahwa konselor sebaya merasa belum memiliki pengalaman dan keterampilan dalam melakukan konseling sebaya. Konselor sebaya yang terbentuk masih merasa bingung dan kurang yakin dapat melaksanakan tugas sebagai seorang konselor sebaya dengan baik. Meskipun demikian, konselor sebaya menyatakan bersedia untuk mengikuti kegiatan-kegiatan pendampingan bagi konselor sebaya. Konselor sebaya berharap dengan mengikuti kegiatan tersebut bisa meningkatkan pengetahuan dan kemampuan sehingga konselor sebaya yakin bisa menjalankan tugasnya sebagai konselor sebaya dengan baik.

Hasil analisis kebutuhan tersebut menunjukkan bahwa konselor sebaya belum memiliki efikasi diri yang baik. Konselor sebaya merasa belum mampu menjalankan tugasnya dengan baik dikarenakan merasa belum memiliki pengalaman, pengetahuan, dan keterampilan yang terkait dengan tugas sebagai seorang konselor sebaya. Efikasi diri berkaitan dengan keyakinan seseorang dalam menyelesaikan tugas atau kemampuan tertentu. Feist dan Feist (2008) menjelaskan bahwa apa yang dilakukan manusia dalam situasi tertentu sangat tergantung kepada resiprositas, perilaku, lingkungan, dan kondisi kognitif. Selain itu, faktor-faktor yang berkaitan dengan keyakinan bahwa mereka dapat atau tidak dalam menghasilkan perilaku yang diinginkan dalam situasi tertentu. Bandura menyebut ekspektansi-ekspektansi untuk mempengaruhi hasil yang diharapkan semacam ini sebagai self-efficacy (efikasi diri). 
Chirese dkk (Tiego \& Kamore, 2015) dalam penelitiannya menyimpulkan bahwa pelatihan konseling sebaya di sekolah tinggi sejauh ini tidak mencukupi dan sangat kurang. Selain itu penting untuk menyelaraskan materi tambahan yang diberikan pada konselor sebaya. Astiti (2011) dalam penelitiannya menemukan bahwa pelatihan konselor sebaya dan dukungan dari pihak sekolah serta sektor terkait merupakan faktor utama yang berhubungan dengan implementasi konselor sebaya.

Sejalan dengan hal tersebut, Suwarjo (2008) menjelaskan bahwa calon konselor sebaya perlu dibekali kemampuan. Kemampuan tersebut meliputi kemampuan untuk membangun komunikasi interpersonal secara baik, sikap dan keterampilan dasar konseling, keterampilan pemecahan masalah, serta keterampilan mengembangkan resiliensi.

Melihat fakta yang ada, maka konselor sebaya yang sudah terbentuk di SMA X perlu untuk memperoleh pelatihan. Hal ini mengingat konselor sebaya yang saat ini terbentuk merupakan siswa kelas XI dan merupakan konselor baru yang belum memiliki pengalaman dan kompetensi yang cukup sebagai bekal untuk menjalankan perannya sebagai seorang konselor sebaya. Adapun hipotesis yang diajukan adalah Pelatihan Teknik Konseling Kesehatan Remaja dapat meningkatkan efikasi diri konselor.

\section{METODE PENELITIAN}

\section{Desain Penelitian}

Penelitian ini menggunakan desain penelitian one group pretest-posttest design (Seniati dkk, 2015). Di awal penelitian dilakukan pengukuran variabel tergantung, kemudian diberikan manipulasi. Setelah diberikan manipulasi, dilakukan pengukuran kembali terhadap variabel tergantung tersebut dengan alat ukur yang sama.

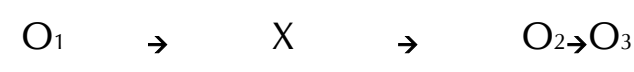

Keterangan:

$\mathrm{O}_{1}=$ Pengukuran prates

$\mathrm{O}_{2}=$ Pengukuran pascates

$\mathrm{O}_{3}=$ Pengukuran tindak lanjut (follow up)

$\mathrm{X}=$ Pelatihan Konseling Kesehatan Remaja

\section{Subjek Penelitian}

Subjek dalam penelitian ini adalah konselor sebaya SMA X kelas XI semester I yang memiliki skor efikasi diri sedang berjumlah tiga orang siswa.

\section{Metode Pengumpulan Data}

Data dikumpulkan menggunakan skala efikasi diri konselor sebaya yang dimodifkasi dari skala efikasi diri akademik yang disusun oleh Wulandari (2013). Skala efikasi diri konselor sebaya terdiri atas 25 butir pertanyaan yang mengacu pada aspek konstruk teori efikasi diri dari Bandura (1997). Skala efikasi diri siswa akselerasi memiliki nilai reliabilitas sebe- 
sar 0,933. Validitas skala efikasi diri siswa akselerasi bergerak antara 0,303 hingga 0,874 .

Pemberian skor pada skala efikasi diri konselor sebaya dilakukan dengan model Likert. Ada empat alternatif respon, yaitu skor 4 untuk jawaban Sangat Sesuai (SS), 3 untuk jawaban Sesuai (S), 2 untuk jawaban Tidak Sesuai (TS), dan 1 untuk jawaban Sangat Tidak Sesuai (STS).

\section{Prosedur Intervensi}

Analisis kebutuhan dilakukan untuk mengetahui kebutuhan peserta pelatihan. Berdasarkan hasil wawancara yang peneliti lakukan, beberapa konselor sebaya menyampaikan bahwa konselor sebaya merasa belum memiliki pengalaman dan keterampilan untuk melakukan peran dan tugasnya sehingga merasa belum mampu atau belum yakin bisa melaksanakan tugas sebagai konselor sebaya dengan baik. Selain itu konselor sebaya merasa perlu untuk dibekali bagaimana cara-cara melakukan konseling yang baik.

Setelah analisis kebutuhan dilakukan, peneliti menyusun modul pelatihan konseling kesehatan remaja. Modul disusun berdasarkan buku Pedoman Teknik Konseling Kesehatan Remaja. Modul pelatihan terdiri atas tiga materi pokok utama yang dibagi menjadi lima sesi materi dan satu sesi presentasi karya. Materi pada sesi pertama terdiri atas materi pengantar konseling sebaya dan kesehatan remaja.
Materi pada sesi kedua meliputi materi tentang sikap dasar seorang konselor. Materi pada sesi ketiga adalah materi teknik konseling. Materi pada sesi keempat dan kelima adalah materi terkait pengantar Pendidikan Keterampilan Hidup Sehat (PKHS) dan komponen dalam pendidikan keterampilan hidup sehat. Materi pada sesi keenam peserta diminta mempresentasikan karya kelompok di hadapan peserta lain.

Pelatihan Konseling Kesehatan Remaja dilaksanakan sebanyak enam sesi di mana masing-masing sesi berlangsung selama 1 - 2 jam. Total intervensi berlangsung selama sembilan jam.

\section{Metode Analisis Data}

Data dianalisis secara kuantitatif dan kualitatif. Analisis kuantitatif dilakukan dengan analisis statistik Nonparametric Wilcoxon test dengan menggunakan program analisis statistik SPSS 16.00 for Windows. Adapun analisis kualitatif dilakukan dengan menggunakan pengelompokkan tema.

\section{HASIL PENELITIAN}

\section{Deskripsi Data Penelitian}

Subjek penelitian pada dasarnya memiliki tujuan khusus ketika menyatakan kesediaannya mengikuti pelatihan. Tujuan yang dimaksud adalah membantu 
orang lain, terutama teman. Hal ini sebagaimana tergambar dari tabel 1 .

Tabel 1. Deskripsi Subjek

\begin{tabular}{llll}
\hline No & Nama & Kelas & Tujuan Menjadi Konselor Sebaya \\
\hline 1. & Subjek 1 & XI MIA 1 & Ingin membantu teman-teman \\
\hline 2. & Subjek 2 & XI MIA 2 & Ingin membantu orang lain. Merasa belum \\
& & & memiliki pengetahuan terkait konselor \\
& & & sebaya sehingga merasa pelatihan konselor \\
& & & sebaya penting \\
\hline 3. & Subjek 3 & XI MIA 2 & Ingin membantu teman-teman \\
\hline
\end{tabular}

\section{Hasil Uji Asumsi}

Berdasarkan hasil uji asumsi, diketahui bahwa nilai uji normalitas sebesar 0,2
( $p>0,05)$. Hal tersebut menunjukkan bahwa sebaran data normal.

Tabel 2. Normalitas Data

\begin{tabular}{llll}
\hline \multicolumn{4}{c}{ Kolmogorov-Smirnov } \\
\hline & Statistic & df & Sig. \\
\hline Pre & .214 & 6 & .200 \\
\hline
\end{tabular}

\section{Hasil Uji Hipotesis}

Tabel 3. Skor Efikasi Diri Prates dan Pascates

\begin{tabular}{lllll}
\hline Subjek & Skor Pretest & $\begin{array}{l}\text { Kategori } \\
\text { persentil }\end{array}$ & Skor Posttest & $\begin{array}{l}\text { Kategori } \\
\text { persentil }\end{array}$ \\
\hline Subjek 1 & 68 & Sedang & 66 & Sedang \\
\hline Subjek 2 & 65 & Sedang & 65 & Sedang \\
\hline Subjek 3 & 66 & Sedang & 70 & Tinggi \\
\hline
\end{tabular}

Hasil perbandingan dari skor prates dengan skor pascates diketahui bahwa setelah mengikuti pelatihan, 1 orang subjek mengalami peningkatan skor efikasi diri, 1 orang subjek tidak mengalami perubahan skor, dan 1 orang subjek mengalami penurunan skor efikasi diri.
Sementara itu, hasil rata-rata skor efikasi diri konselor sebaya mengalami kenaikan dari 66,33 menjadi 67.

Analisis statistik menggunakan Nonparametric Wilcoxon-test diperoleh nilai signifikansi sebesar 0,655 ( $p>0,05)$ yang berarti tidak ada perbedaan yang 
signifikan pada skor efikasi diri konselor sebaya peserta pelatihan sebelum dan setelah mengikuti pelatihan. Hal tersebut berarti pelatihan Konseling Kesehatan Remaja tidak mampu meningkatkan efikasi diri konselor sebaya sebagai peserta pelatihan.

\section{Hasil Analisis Kualitatif}

Subjek 1

Pada awalnya subjek 1 merasa belum bisa menjalankan tugas sebagai seorang konselor sebaya karena merasa belum memiliki cukup bekal. Pada saat pelatihan, subjek 1 cukup kooperatif dalam mengikuti pelatihan. Secara umum, subjek 1 tidak terlalu aktif seperti peserta yang lain. Meskipun demikian, subjek 1 mampu merespon setiap pertanyaan yang diberikan oleh trainer pada saat pelatihan berlangsung.

Dari hasil wawancara diketahui bahwa subjek 1 merasa mendapatkan pengetahuan baru terkait bagaimana melakukan konseling. Subjek 1 merasa hal tersebut bermanfaat pada saat menjalankan tugas sebagai seorang konselor sebaya. Selain itu, subjek 1 mengaku bahwa keterampilan untuk melakukan konseling juga berubah, misalnya belajar mendengarkan aktif, melakukan refleksi dan tahapan-tahapan dalam konseling. Meskipun demikian, subjek 1 mengatakan bahwa tugas menjadi konselor sebaya tidaklah mudah karena memiliki tuntutan untuk menjadi contoh bagi teman yang lain. Subjek 1 juga merasa senang ketika mengikuti outbond. Subjek 1 merasa pelajaran yang didapat pada saat outbond akan bermanfaat.

Pada hasil wawancara yang dilakukan di akhir penelitian, subjek 1 menyampaikan bahwa setelah pelatihan ada beberapa teman sekelas yang sering curhat. Adapun permasalahan yang diceritakan adalah seputar permasalahan cinta, permasalahan dengan teman, serta permasalahan keluarga. Subjek 1 menyampaikan bahwa belum semua tahapan proses konseling dilakukan seperti pada saat pelatihan karena sudah mengenal teman yang melakukan konseling. Subjek 1 mengaku sudah mampu menggali permasalahan dan mencoba mendengarkan seperti pada saat pelatihan. Akan tetapi, yang menjadi hambatan bagi subjek 1 adalah ketika membantu mencarikan solusi dan jika terkait dengan permasalahan yang berat atau masalah keagamaan. Subjek 1 juga merasa lebih yakin dalam melaksanakan tugas sebagai konselor sebaya. 


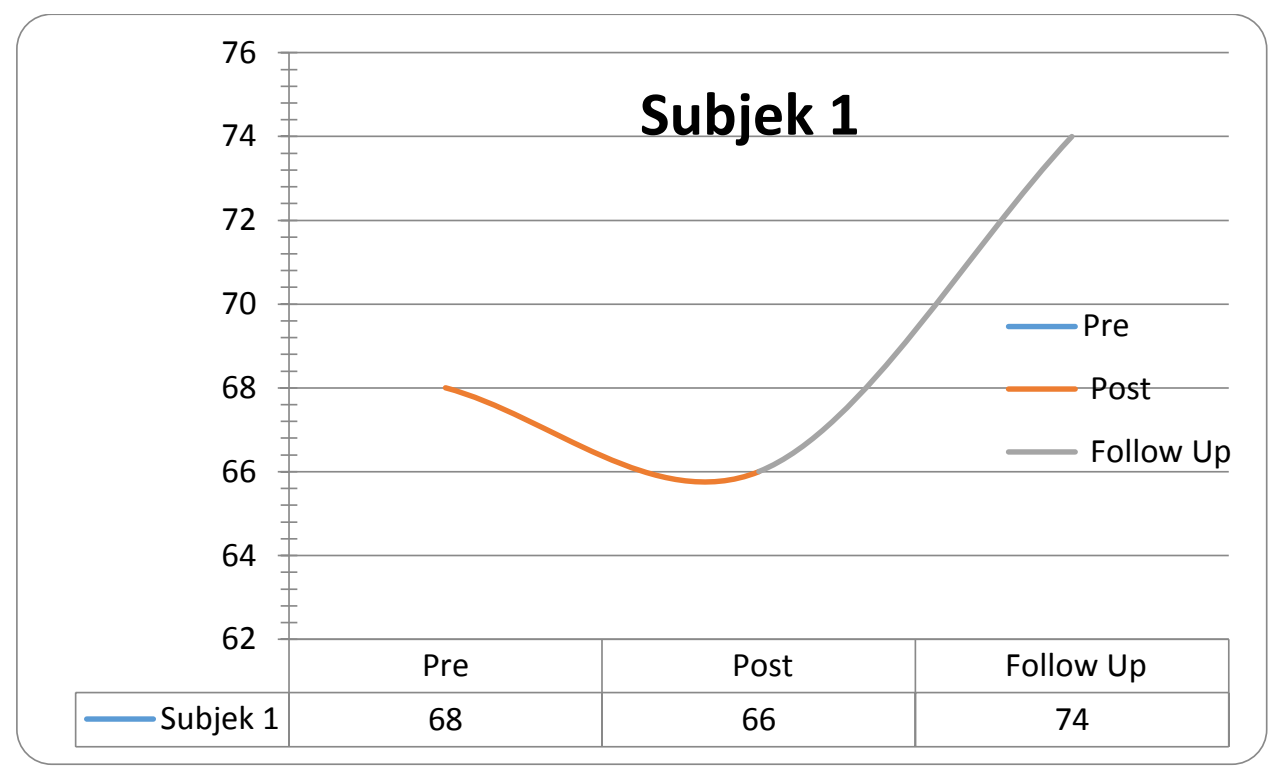

Grafik 1. Skor Efikasi Diri Subjek 1

Subjek 2

Pada awalnya subjek 2 masih merasa bingung dan kurang yakin dapat melaksanakan tugas sebagai seorang konselor sebaya dengan baik. Meskipun demikian, subjek 2 menyatakan bersedia untuk mengikuti kegiatan-kegiatan pendampingan bagi konselor sebaya. Subjek 2 berharap dengan mengikuti kegiatan tersebut bisa meningkatkan pengetahuan dan kemampuan sehingga yakin bisa menjalankan tugasnya sebagai konselor sebaya dengan baik.

Secara umum, subjek 2 cukup aktif pada saat pelatihan. Subjek 2 juga menunjukkan minat dan perhatian pada saat trainer memberikan penjelasan, subjek 2 juga aktif bertanya dan memberikan komentar pada saat pelatihan. Subjek 2 terlihat memiliki inisiatif lebih tinggi dibandingkan peserta lain. Sebagai contoh misalnya, pada saat trainer memberikan pertanyaan, subjek 2 bersedia menjadi contoh bagi peserta lain.

Subjek 2 menyatakan bahwa pelatihan tersebut sangat bermanfaat karena memberikan tambahan pengetahuan dan pengalaman kepada subjek 2 untuk menjalankan tugas sebagai konselor sebaya. Subjek 2 menyatakan bahwa ketika sering dilatih, maka keterampilan peserta akan meningkat dan peserta terbiasa untuk mempraktekkan materi yang didapatkan dari pelatihan. Subjek 2 mengaku belajar bagaimana menjadi seorang konselor sebaya, cara mendengarkan aktif, dan cara mengelola emosi.

Pada saat pertemuan tindak lanjut, subjek 2 menyatakan bersedia untuk menjadi konselor sebaya meskipun pada 
awalnya terjadi salah paham antara subjek 2 dengan peneliti. Pada awalnya subjek 2 berpikir jika pertemuan akan terus dilaksanakan secara berkala setiap hari Kamis. Subjek 2 mengaku merasa keberat- an jika pertemuan rutin dilaksanakan setiap hari Kamis. Namun, setelah diberikan penjelasan, subjek 2 akhirnya memahami dan tetap bersedia menjadi konselor sebaya.

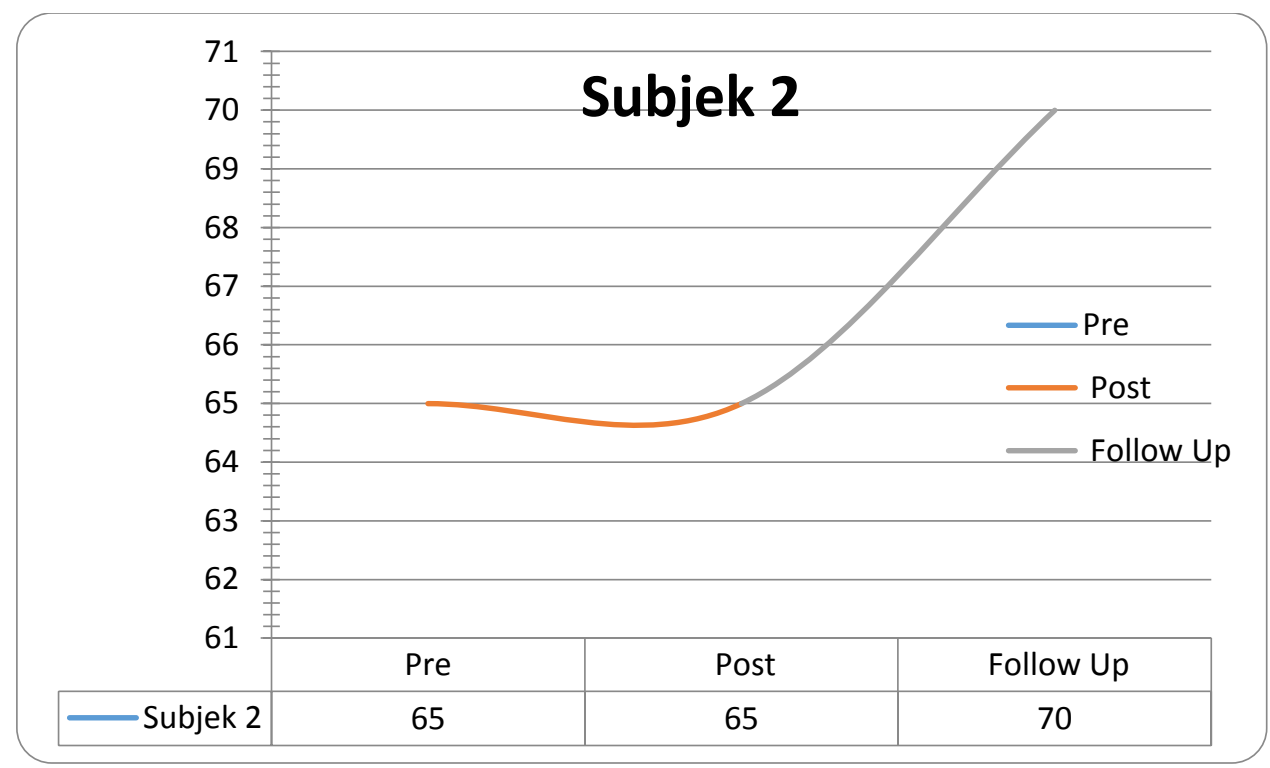

Grafik 2. Skor Efikasi Diri Subjek 2

Subjek 3

Subjek 3 bersedia menjadi konselor sebaya dengan alasan ingin membantu teman-teman. Pada pertemuan pertama, subjek 3 cukup aktif dengan bertanya kepada trainer. Subjek 3 juga terlihat memperhatikan (menyimak) teman yang sedang menyampaikan pendapat. Selain itu, subjek 3 mau bertindak sebagai juru bicara kelompok ketika presentasi hasil diskusi. Secara umum, subjek 3 cukup kooperatif mengikuti pelatihan meskipun tidak terlalu aktif.
Setelah pelatihan, subjek 3 merasa memiliki pengetahuan baru terkait konseling sebaya serta dapat melakukan introspeksi diri untuk menjadi pribadi yang lebih baik. Subjek merasa memperoleh manfaat yaitu bisa lebih mengerti diri sendiri, bisa mengontrol rasa ingin tahu yang berlebih dan bisa menahan emosi. Selain itu, subjek merasa lebih bisa memahami lingkungan sekitar, lebih peka dengan sesama, dan berpikir panjang sebelum mengambil keputusan.

Pada saat tindak lanjut, subjek 3 menjelaskan bahwa sudah ada klien yang 
ditanganinya yaitu teman-teman di sekolah. Subjek mencoba untuk menerapkan apa yang telah didapatkan dari pelatihan, meskipun masih belum sepenuhnya mampu diterapkan karena merasa canggung. Hal tersebut terjadi karena klien yang ditangani adalah teman yang sudah dekat. Subjek merasa masih takut jika belum bisa memahami orang lain. Misalnya, subjek khawatir jika saran yang diberikan kepada klien keliru dan mengakibatkan permasalahan klien menjadi panjang.

Subjek 3 merasa lebih yakin dan mampu melaksanakan tugas sebagai seorang konselor sebaya dan merasa ada kemajuan dari sebelumnya. Hal tersebut dikarenakan subjek 3 sudah mempelajari dan mempraktikkan keterampilan konseling ketika ada teman di sekolah yang bercerita (curhat) kepada subjek 3 .

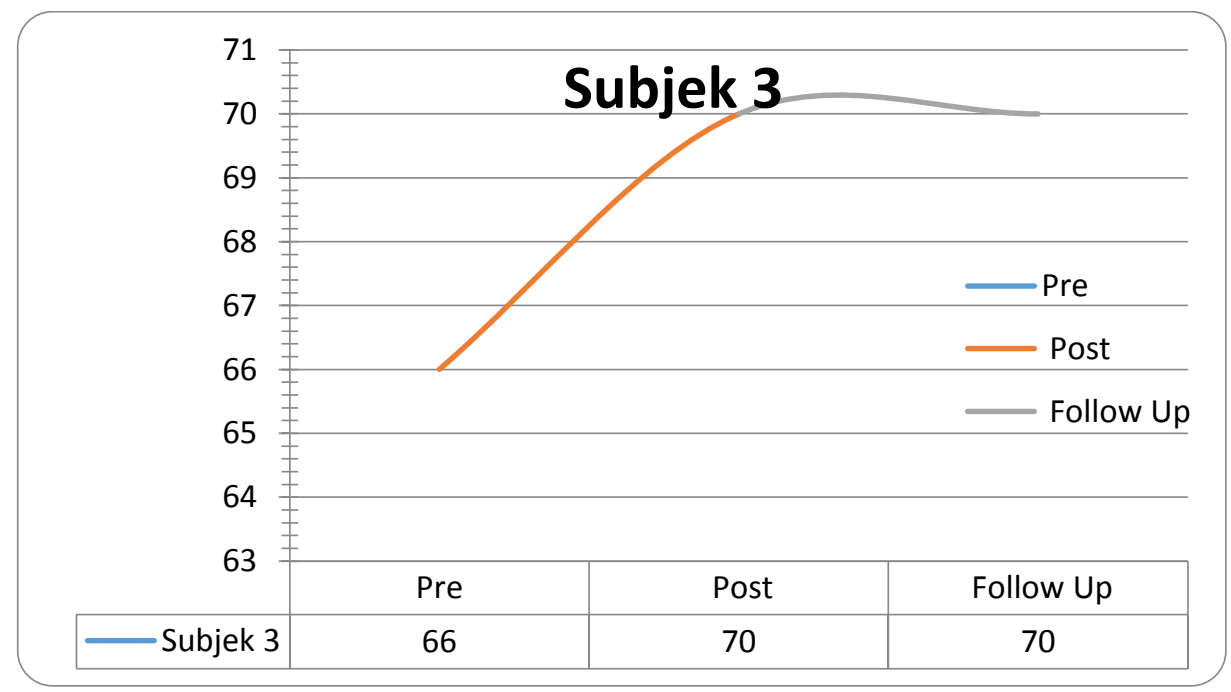

Grafik 3. Skor Efikasi Diri Subjek 3

\section{PEMBAHASAN}

Hasil analisis statistik menunjukkan tidak ada pengaruh yang signifikan Pelatihan Konseling Kesehatan Remaja terhadap efikasi diri konselor sebaya. Meskipun demikian, terdapat perubahan nilai rata-rata pada subjek dan terjadi peningkatan skor efikasi diri konselor sebaya pada tiga subjek.
Robinson dan Christensen (Seniati, Yulianto, \& Setiadi, 2015) menyatakan ada beberapa faktor yang dapat mempengaruhi kekuatan hubungan sebab-akibat antara variabel bebas dengan variabel tergantung, yaitu proactive history, retroactive history, maturation, testing, statistical regression, experimental mortality, interaction effect, instrumentation 
effect, experimenter effect, serta participant sophistication.

Dari beberapa faktor tersebut, peneliti berpendapat bahwa faktor proactive history, retroactive history, testing, dan instrumentation effect mempengaruhi kekuatan hubungan sebab akibat antara Pelatihan Konseling Kesehatan Remaja dengan efikasi diri konselor sebaya.

Dari ketiga orang subjek, satu orang subjek mengalami penurunan skor efikasi diri dan satu subjek tidak mengalami perubahan skor. Hal tersebut terjadi kemungkinan karena setelah mengikuti pelatihan subjek merasa bahwa tugas sebagai konselor cukup berat karena membutuhkan kompetensi dan sikap yang baik. Penilaian konselor sebaya terhadap diri sendiri yang merasa belum seperti sosok ideal sebagai seorang konselor mengakibatkan penurunan skor efikasi diri konselor sebaya.

De Rosenroll (Geldard, 2014) menyampaikan bahwa isu-su yang menyangkut atribusi peran tampaknya juga menjadi persoalan terkait kegiatan menolong atau kewajiban yang dijalankan oleh remaja, khususnya jika istilah "peer counselor/helper" digunakan sehingga mengandung ekspektasi-ekspektasi profesional. Ketika diberi label sebagai konselor sebaya seseorang akan dianggap memiliki peran berbeda dan kemungkinan akan mengganggu ekspektasi teman sebaya bahwa seharusnya hubungan yang terjadi timbal balik dan setara.

Hal tersebut seperti diungkapkan oleh subjek 1 yang merasa bahwa menjadi seorang konselor sebaya membutuhkan sosok yang ideal serta bagaimana bersikap sebagai seorang konselor sebaya di sekolah. Selain itu, subjek 2 juga menyatakan bahwa dirinya belum bisa dijadikan contoh yang baik bagi teman-teman yang lain karena terkadang ada hal-hal yang tidak sesuai sebagai seorang konselor sebaya. Meskipun demikian, subjek 1 dan subjek 2 menyatakan siap melaksankan tugas sebagai seorang konselor sebaya karena memiliki pengetahuan baru terkait teknik untuk melakukan konseling. Dari hasil analisis kualitatif, diketahui semua subjek menyatakan siap menjadi seorang konselor sebaya dan beberapa subjek merasa yakin bisa melaksanakan tugasnya meskipun masih perlu belajar.

Selain karena faktor di atas, penurunan efikasi diri konselor sebaya terjadi kemungkinan disebabkan peserta mengalami hambatan ketika mencoba mengimplementasikan keterampilan konseling pada saat konseling berlangsung. Beberapa peserta mengaku tidak terbiasa menggunakan keterampilan tersebut dan merasa lebih nyaman dengan menggunakan cara yang biasa mereka lakukan seperti cara berkomunikasi, mengarahkan, memberikan pandangan lain dan 
memberikan solusi. Hal tersebut seperti yang diungkapkan oleh subjek 1 , subjek 2 dan subjek 3."Gak biasa pake tahapantahapan" (subjek 1 dan subjek 2). "Kalo untuk penerapan yang kayak salam dan lain-lain belum terlalu diterapin karena agak canggung kalo sama temen sekelas, khan udah deket. Tapi tetep kalo kayak perhatian penuh terus ngasih saran jika diperlukan tetap dilakukan" (subjek 3).

Tekait impelementasi keterampilan, Carr (Geldard, 2014) mengakui bahwa begitu keterampilan konseling inti telah dikuasai, remaja mungkin merasa ganjil, mekanik, atau palsu. Hal ini tidak mengejutkan karena penelitian telah menunjukkan bahwa keterampilan-keterampilan konseling yang diajarkan di dalam program belum kompatibel dengan prosesproses konversasional tipikal remaja (Geldard, 2006).

Salah satu dimensi dari efikasi diri adalah tingkat kesulitan. Ketika konselor sebaya mempelajari keterampilan konseling baru kemudian merasakan memiliki tingkat kesulitan tinggi maka hal tersebut bisa menurunkan efikasi diri. Hal tersebut juga diperkuat dari hasil analisis per butir soal subjek 1 dan subjek 2 di mana ditemukan penurunan skor efikasi diri terjadi pada butir-butir yang termasuk ke dalam dimensi tingkat kesulitan.

Geldard (2014) dalam sebuah penelitian menemukan bahwa beberapa microskill konseling yang digunakan dalam melatih remaja menjadi konselor sebaya tidak mudah digunakan dan dianggap tidak membantu remaja. Keterampilan-keterampilan mikro konseling seperti refleksi dan merangkum, dipersepsikan sulit dan tidak membantu dalam helping conversation dengan sesama remaja. Sebuah proses problem solving dan pertanyaan-pertanyaan terbuka dan tertutup mudah digunakan dan dianggap berguna. Geldard juga menemukan bahwa beberapa perilaku konversasional remaja yang telah dilarang pada program-program pelatihan konselor sebaya sebenarnya berguna ketika remaja saling membantu satu sama lain, misalnya menentramkan, memberi saran, meng-alihkan perhatian, dan sebagainya.

Faktor kondisi fisik dan emosi juga turut berpengaruh dalam penelitian. Pada saat pengisian pascates, peserta dalam kondisi lelah, kehujanan dan sudah sore hari sehingga mempengaruhi proses pengukuran. Bandura (Feist \& Feist, 2010) menyebutkan bahwa salah satu pembentuk efikasi diri adalah kondisi fisik dan emosi. Emosi yang kuat biasanya menurunkan tingkat performansi. Ketika mengalami rasa takut yang besar, kecemasan yang kuat, dan tingkat stres yang tinggi, individu memiliki ekspektansi efikasi diri yang rendah.

Faktor lain yang mungkin berpengaruh adalah waktu yang digunakan untuk melatih keterampilan konseling 
kurang lama serta metode yang disusun dalam modul pelatihan. Untuk menumbuhkan efikasi diri konselor sebaya tidak bisa diperoleh dalam waktu yang instan.Selain itu, diperlukan praktik yang dilakukan oleh konselor secara mandiri dengan dipandu lembar penugasan praktik mandiri. Hal tersebut sebagaimana yang disampaikan oleh Geldard (2014) di mana desain pelatihan yang dilakukan menghabiskan waktu 16-18 jam pelatihan konselor sebaya dan dilaksanakan oleh dua orang pelatih berpengalaman yang biasanya dilaksanakan selama tiga hari berturut-turut dengan istirahat reguler untuk makan siang dan penyegaran. Astiti (2011) dalam penelitiannya menemukan bahwa salah satu hasil yang diperoleh dalam pelatihan konselor sebaya adalah lama pelatihan yang singkat dan waktu pelatihan yang dilaksanakan sampai larut malam.

Selain itu, kondisi awal efikasi diri subjek dari hasil pengukuran menunjukkan berada pada kategori sedang dan tinggi. Secara statistik tidak ada pengaruh yang signifikan pada peserta. Meskipun demikian, terdapat peningkatan nilai ratarata subjek penelitian. Efek pelatihan kemungkinan akan lebih berpengaruh jika efikasi diri subjek berada pada kondisi rendah dan akan kurang terlihat jika subjek pada tingkat sedang atau tinggi.

\section{SIMPULAN DAN SARAN}

\section{Simpulan}

Berdasarkan analisis data dan pembahasan yang dilakukan diketahui bahwa Pelatihan Konseling Kesehatan Remaja tidak mampu meningkatkan efikasi diri konselor sebaya SMA. Hasil analisis data secara kualitatif menunjukkan adanya perubahan skor efikasi diri pada subjek penelitian setelah diberikan intervensi. Subjek penelitian merasa yakin bisa melaksanakan tugas sebagai konselor sebaya.

\section{Saran}

Pelatihan Konseling Kesehatan Remaja secara kualitatif terbukti memiliki manfaat yang positif bagi subjek penelitian. Hal-hal yang sudah dipelajari sebelumnya agar bisa diterapkan ketika subjek menjalankan tugas sebagai konselor sebaya. Selain itu, diharapkan agar subjek melakukan pertemuan secara berkala dengan guru BK, sesama konselor sebaya, maupun psikolog puskesmas untuk melakukan tindak lanjut setelah pelatihan diberikan. Pihak sekolah diharapkan melakukan tindak lanjut dengan melakukan pembinaan kepada konselor sebaya yang sudah diberi pelatihan. Selain itu, diharapkan adanya koordinasi secara berkala dengan konselor sebaya maupun pihak Puskesmas. 
Peneliti selanjutnya perlu untuk mempertimbangkan lama waktu pelatihan. Efikasi diri dibentuk salah satunya oleh pengalaman tentang penguasaan. Semakin lama waktu yang digunakan untuk melakukan praktek konseling, kemungkinan semakin meningkatkan efikasi diri. Selain itu, peneliti selanjutnya diharapkan juga mendesain modul yang memang memudahkan dan sesuai dengan tipikal konselor sebaya pada siswa SMA.

\section{DAFTAR PUSTAKA}

Astiti, N.M. (2011). Hubungan faktor pelatihan kesehatan reproduksi dengan implementasi pasca pelatihan pada konselor sebaya kesehatan reproduksi remaja di Provinsi Bali. Tesis (tidak dipublikasikan). Denpasar: Program Magister Program Studi Ilmu Kesehatan Masyarakat Universitas Udayana.

Bandura, A. (1997). Self-efficacy: The exercise of control. New York: W.H. Freeman and Company.

Feist, J. \& Feist, G.J. (2008). Theories of personality. Yogyakarta: Pustaka Pelajar.

Geldard, K. (2014). Konseling remaja intervensi praktis bagi remaja beresiko. Yogyakarta: Pustaka Pelajar.
Kementrian Kesehatan RI. (2013). Pedoman Standar Nasional Pelayanan Kesehatan Peduli Remaja (PKPR). Jakarta: Kementrian Kesehatan RI.

Kementrian Kesehatan RI. (2013). Pedoman teknik konseling kesehatan remaja bagi konselor sebaya. Jakarta: Kementrian Kesehatan RI.

Santrock, J.W. (2002). Life-span development. Jakarta: Erlangga.

Seniati, L., Yulianto, A., \& Setiadi, B.N. (2015). Psikologi eksperimen. Jakarta: Indeks.

Suwarjo. (2008). Konseling teman sebaya (peer counseling) untuk mengembangkan resiliensi remaja (makalah disampaikan dalam Semi-nar Pengembangan Ilmu Pendidik-an Fakultas Ilmu Pendidikan Universitas Negeri Yogyakarta tanggal 29 Februari 2008.

Tiego, M.P \&Kamore, S.K. (2015). Four Pillars of effectiveness of peer counselling programs in Meru South District High Schools, Kenya. Intervational Journal of Humanities and Sosial Science, 5(2), 254-262.

Wulandari, S. (2013). Hubungan antara hubungan antara efikasi diri dan stres akademik pada siswa Sekolah Menengah Atas (SMA) yang mengikuti program akselerasi. Skripsi. Yogyakarta: Universitas Islam Indonesia. 
Muhammad Arif Rizqi, H. Fuad Nashori, \& Yulianti Dwi Astuti

58 | Jurnal Intervensi Psikologi Vol. 9 No. 1 Juni 2017 


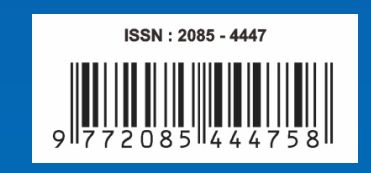

